Check for updates

The BMJ

Cite this as: BMJ 2021;375:n3001 http://dx.doi.org/10.1136/bmi.n3001 Published: 03 December 2021

\title{
Covid-19: "Deficient" risk assessment system left UK exposed, says Lords report
}

\section{Gareth lacobucci}

The UK remains vulnerable to the impact of extreme risks such as the covid-19 pandemic because its system for assessing and managing risks is too centralised and secretive, a House of Lords committee has concluded.

In a report published on 3 December, ${ }^{1}$ the House of Lords Risk Assessment and Risk Planning Committee said that the UK must become better at anticipating, preparing for, and responding to a range of challenging risk scenarios, including those not experienced before.

The committee chair, James Arbuthnot, said, "The government's risk management system defaults to a secretive and centralised approach that withholds safety critical information from those who need it-shielding it from full scrutiny and challenge.

"Before covid struck, we as a country knew that a pandemic was among the top risks that we faced. The government had been advised that in the event of a coronavirus pandemic, the country would suffer up to 100 deaths. Given that more than 140 ooo people have now died in the UK, it is clear that we needed to re-examine our system of assessing and planning for extreme risks."

In its report the committee urged the government not to default to secrecy in the risk assessment process, which it argued hampered preparedness during the pandemic by making it hard for other agencies such as local government, volunteer groups, and businesses to access the information they needed to ensure the country's safety.

To increase transparency, ministers should replace the current risk assessment process with "a more dynamic, data driven output, directly linked to preparation, mitigation and response," the committee said. The UK should produce a "National Security Risk and Resilience Assessment" that places more emphasis on preparedness and resilience and welcomes a higher degree of expert scrutiny, it added.

\section{Changing risks}

The committee argued that the government's time and resources were too focused on responding to crises and emergencies, from flooding to terrorist attacks.

"We must place a premium on possessing the competence, capacity, and skills to manage these crises," it said. "Risk plans must be frequently tested, challenged, and scrutinised ... Government spending should, where possible, be directed towards preparing for, preventing, and mitigating disaster."

The committee highlighted that the risks being faced were changing, noting the impact of technological advances; the failure of ageing critical infrastructure such as nuclear power stations, dams, and bridges; and a reliance on electricity, integrated smart systems, and the internet. It also emphasised that many risks were likely to be exacerbated by climate change.

Other recommendations for government included:

- Establishing an Office for Preparedness and Resilience, which should produce independent analysis of UK preparedness

- Publishing the content of the Official-Sensitive National Security Risk Assessment, except where there is a direct national security risk

- Giving parliament a more active role in scrutinising preparedness for risk

- Engaging industry and businesses more when developing risk assessments, and

- Committing to a biennial publication of a brochure to inform the public on risk preparedness.

Arbuthnot said, "Our inquiry has concluded that the UK must adopt a 'whole of society' approach to resilience, one which emphasises the important role played by all sections of society in preparing for, adapting to, and recovering from the effects of risk."

1 House of Lords Select Committee on Risk Assessment and Risk Planning HL Paper 110, Report of Session 2021-22. Preparing for extreme risks: building a resilient society. 3 Dec 2021. https://committees.parliament.uk/committee/483/risk-assessment-and-risk-planning-committee/publications/

This article is made freely available for use in accordance with BMJ's website terms and conditions for the duration of the covid-19 pandemic or until otherwise determined by BMJ. You may use, download and print the article for any lawful, non-commercial purpose (including text and data mining) provided that all copyright notices and trade marks are retained. 